\title{
Potential Barriers to the Implementation of Digital Game-Based Learning in the Classroom: Pre-service Teachers' Views
}

\author{
Polyxeni Kaimara $^{1}$ (D) Emmanuel Fokides ${ }^{2}$ (D) Andreas Oikonomou $^{3}$. \\ loannis Deliyannis ${ }^{1}$ (ic
}

Accepted: 27 March 2021 / Published online: 7 April 2021

(C) The Author(s), under exclusive licence to Springer Nature B.V. 2021

\begin{abstract}
Teachers seek to attract students' attention by demonstrating the relevance of learning content to daily activities and enhancing their students' self-esteem and satisfaction. In the digital world, an example of an innovative learning tool is digital games. Digital game learning (DGBL) is a smart pedagogical approach that utilises digital games. DGBL has a prominent place in learning technologies due to the potentiality of games to engage students, enabling them to effortlessly reach the edges of their competencies, skills, and knowledge. Teachers, students and games per se constitute important agents for the successful and effective implementation of DGBL. In this context, our research was extended to cover the study of teachers' and students' perceptions of DGBL. More specifically, the purpose of this research was to examine the pre-service teachers' perceptions of the barriers to DGBL implementation. To that end, an online survey with closed-ended questions and one open-ended question was conducted. In this paper, we present the answers to the open-ended question. Quantitative and qualitative data processing and analysis were carried out. According to the pre-service teachers' responses, it is concluded that a major obstacle is the inefficient allocation of available financial resources. Resources are required for the supply of up-to-date equipment, devices and educational software, as well as for the professional development and training of teachers, school administrators and policymakers. Utilizing easy-to-use and inexpensive devices, which most teachers and even students hold, is the answer to the hurdle called "lack of equipment". Therefore, the implementation of the DGBL, as a smart and innovative pedagogical approach, is primarily a matter of political will to curriculum reform based on ongoing research into appropriate digital learning materials.
\end{abstract}

Keywords Barriers · Digital games · Digital game-based learning · Learning technologies · Pre-service teacher attitudes $\cdot$ Smart pedagogy

Polyxeni Kaimara

a16kaim@ionio.gr

Extended author information available on the last page of the article 


\section{Introduction}

The importance of prompting students to engage in learning activities through gamelike experiences is well-documented. Games have been proven as a universal component of human experience and development in all cultures and constitute one of the oldest forms of designed human interaction that promotes learning (Ifenthaler et al., 2012; Plass et al., 2015; Salen \& Zimmerman, 2004). Researchers have identified that the association between play and learning is a lifelong process based on five games characteristics: joy, meaning, engagement, iterative and social interaction (Zosh et al., 2017). When children explore the physical nature of things during playing, also exercise along five distinct axes of freedom: (a) freedom to fail, (b) freedom to experiment, (c) freedom to fashion identities, (d) freedom of effort, and (e) freedom of interpretation (Klopfer et al., 2009). It is this sense of freedom that creates the conditions of children's effortless involvement with any activity that resembles a game. The key feature of games is the control that children exercise over the game as they never have real control in their daily lives. Thus, we consider that the feeling of control and opportunities provided for decision-making in playful activities without the fear of failure can help children understand their role as active explorers of their social and physical environment (Gee, 2008; Gray, 2008; Hewes, 2014). In the digital era, contemporary research has already recognised the power of digital games to capture children's attention and to motivate them to explore the edges of their competence, skills and knowledge (De Grove et al., 2012; Fokides, 2020; Kaimara \& Deliyannis, 2019; Keller, 2016; Megagianni \& Kakana, 2021; National Academies of Sciences Engineering \& Medicine, 2018; Plass et al., 2015).

A smart pedagogical approach promotes the synergy between technology and pedagogy and utilises digital games in the learning process (Daniela, 2020). Learning that employs digital games is also known as digital game-based learning (DGBL) (Daniela, 2019; Daniela \& Lytras, 2018; Erhel \& Jamet, 2019; Kaimara \& Deliyannis, 2019; Plass et al., 2015; Prensky, 2007). DGBL is a combination of serious learning and interactive entertainment and could be seen as the new paradigm for education (de Freitas \& Liarokapis, 2011; Prensky, 2007). Several studies provide measurable evidence that DGBL boosts learning outcomes (Clark et al., 2016; Fokides, 2020; Gee, 2008; Girard et al., 2013; Hamari et al., 2016; Hersh \& Leporini, 2018; Kaimara et al., 2020). Although the evidence of DGBL effectiveness is strong, there are also those academic voices who claim that digital games are largely ineffective and ill-suited to school structure. Consequently, DGBL has no place in the classroom, as it does not have much to offer compared to traditional teaching methods, such as lectures (Becker, 2010; Clark, 2007; Watson et al., 2013). Possibly, these conclusions may not be entirely accurate, as many teachers seem to rely on the digital media themselves for admittedly provocative and challenging instruction that therefore have the potential to engage students and they do not focus adequately on the cognitive process involved in the meaningful learning (Clark et al. 2010). Over the past decades, contrasting voices concerning the educational benefits of digital games have been based on the common perception that digital games were arcade-style entertainment and therefore difficult to value their educational potential (Schrader et al., 2006). Although studies on the cognitive consequences of games focus on Commercial-Off-the-Shelf (COTS) games designed for entertainment rather than for cognitive skills or learning outcomes, there is evidence that they could improve cognitive skills such as problem-solving, memory, attention and spatial knowledge (Hébert et al., 2021; Kaimara et al., 2019a; Mayer, 2019). On the other hand, brain training games that contain a series of mini-games do not provide convincing 
evidence of their effectiveness, perhaps due to the absence of focus on a single skill but on a collection of different games which are addressed to different cognitive skills (Makransky et al., 2019; Mayer, 2019). Hence, the reasonable question that arises is what are the features of a digital game that make it educational. The most positive element of playful activities is the child's engagement, as games give pleasure, motives and excitement (Huizenga et al., 2017). However, putting educational content into games with the expectation of motivating children is not enough to perceive a digital game as an educational one (Gunter et al., 2006).

Even if the motivation is a good starting point for games to be integrated into education, games should be aligned with the principles of pedagogy and educational methodology, as well. The educational methodology that supports games' integration is based on the theoretical framework called Technological Pedagogical and Content Knowledge (TPACK). This framework refers to the dynamic association between three categories of knowledge: (a) content, (b) pedagogy and (c) technology and suggests that educational technology requires teachers' professional development and training (Mishra \& Koehler, 2006; Spiteri \& Chang Rundgren, 2020). Teachers' training aims both of fostering their positive attitudes towards the integration of technology and promoting good practices in the learning process. Whatever changes and innovations are made in teaching and learning theory and practice, teachers remain the heart and the lever of the educational process, as they are those who will be called upon to apply them in the classroom (Bell \& Gresalfi, 2017; Kaimara et al., 2019b; OER, 2018). Teachers' attitude towards new teaching methods is one of the key factors that contribute to their implementation and influence students' motivation to learn (Martín-del-Pozo et al., 2019). Therefore, there is a continuing need for empirical research that addresses the particular challenges of implementing DGBL in a variety of classroom contexts, taking into account the barriers that teachers themselves face in optimizing DGBL (Hébert et al., 2021).

Recent findings concluded that teachers were unwilling to use digital educational games because they were not really convinced that games are very useful for enhancing their job. Teachers' personal experiences, and mainly their own limited playing experience, workload, perceived self-efficacy with ICT and perceptions of significant others, such as those of students, parents, fellow teachers and experts, play a notable role in shaping their attitudes toward DGBL (Bourgonjon et al., 2010, 2013; Daniela \& Žogla, 2013; Fokides \& Kaimara, 2020; Hamari \& Nousiainen, 2015; Mertala, 2019; Sánchez-Mena \& Martí-Parreño, 2017; $\mathrm{Wu}, 2015)$. These results suggest that perceived value is an important driver for implementing pedagogical innovations like digital games. Sánchez-Mena and MartíParreño (2017) conducted a study on university teachers' perceptions about the drivers and the barriers to adopting gamification, i.e., the use of game design elements in non-game settings (Deterding et al., 2011), in their courses. Alongside the drivers that encourage teachers to use gamification in their courses, such as attention, motivation, entertainment, interactivity and ease to learn, four major barriers were found: (a) lack of resources (time, training, classroom settings and financial support), (b) students apathy (lack of interest or a perceived waste of time), (c) subject fit (lack of knowledge to achieve the learning goals, useful for some subjects but not for all, obstacles for complying with the teaching schedule) and (d) classroom dynamics (disturbance of classroom/atmosphere, potential conflict with other teachers) (Sánchez-Mena \& Martí-Parreño, 2017). These findings are consistent with early conclusions from previous surveys regarding the factors which influence teachers' decisions to use games and generally ICT in the classroom: lack of expertise in applying new methodologies, anxiety while facing technological innovations, students' and teachers' interest, lack or difficulty in accessing resources, lack of time, game availability, quality 
of software and hardware, ease of use, incentives to change, game content and its alignment with learning objectives, support and collegiality in their schools, classroom management, school and national policies, commitment to professional learning and background in formal computer training (Bensiger, 2012; Goodwyn et al., 1997; Jimoyiannis \& Komis, 2007; Mumtaz, 2000; Papadakis, 2018; Pivec, 2007; Watson et al., 2013).

DGBL acceptance is considered a part of the wider framework of educational technology acceptance. Davis (1986) developed a test as a theoretical model, namely Technology Acceptance Model (TAM), to improve the understanding of user acceptance and to provide a methodology that would enable system designers to evaluate proposed new systems before their implementation. According to TAM, the primary factors that influence an individual's intention to use new technology are the perceived ease of use and the perceived usefulness. Ertmer (1999) identified two major categories of barriers to the integration of technology into the educational process: external and internal barriers. External barriers (first-order) include limited technological equipment, access, teacher training and support, and internal (second-order) comprise teachers' beliefs about their role relating to students' role, curriculum and assessment practices. Close to Elmer's suggestions are the results of Koh et al. (2012) study. Teachers' perception was influenced by external factors such as policies and curriculum and internal factors, i.e., personal interest and attitudes towards gaming. Even if teachers are skilled enough in technology and first-order barriers are resolved, they cannot still apply appropriate ICTs in their teaching due to the internal barriers, such as their views and attitudes towards ICTs in education based on their pedagogical beliefs (Fokides \& Kostas, 2020). In this context, Tomczyk et al. (2020) identified four categories of teachers' attitudes towards new media: techno-optimist, techno-realist, techno-pessimist, and techno-ignorant. Techno-optimist teachers are enthusiastic and realize that new media could positively affect the quality and effectiveness of education. Techno-realists react with careful and critical thinking to the new possibilities presented by the new media, without this attitude implying a reluctance to adapt to technological progress. Techno-pessimists believe that new technologies are useless or even unfavourable for human development. Finally, the techno-ignorant is characterized by a lack of participation in the learning process by using new media.

Consequently, researches regarding teachers' behavioural intention to use educational games in their courses concluded that perceived usefulness influences directly and positively teachers' intention while, gender and age were not found to have an impact on teachers' attitudes (Sánchez-Mena et al., 2017a, 2017b). Besides the in-service teacher target group, studies have found that most pre-service teachers have access to video game consoles, enjoy video games, and are willing to use them as educational tools in their classrooms, thus extending their teaching skills. Pre-service teachers believed that the integration of video games in their classrooms would help their students to pay more attention and develop their social and academic skills. However, they mentioned a serial of barriers such as lack of the appropriate educational video games, lack of technical equipment, training and financial assistance and lack of support from school administrations (Bensiger, 2012; Van Eck et al., 2015). Martín-del-Pozo et al. (2017), also, argued that pre-service teachers had positive attitudes towards collaborative learning through video games and had the willingness to use them in their educational practices.

Any pedagogical approach takes time to incorporate new practices, especially when considering the complexity of the educational intervention, such as the gamification of learning. Although gamification differs from DGBL, it is an excellent passage to provide the principles of DGBL, including just-in-time learning, active, not passive learning, critical thinking and interrelations within and across multimode systems (e.g., images, words, 
actions, symbols, artefacts, etc.), collaboration and teamwork, engagement and choice (Gee, 2003). Additionally, studies highlight that skills, such as critical thinking, communication, collaboration and creativity, which are developing by students while playing games, are essential for 21 st-century education (Kaimara et al., 2020; Kaimara \& Deliyannis, 2019). Moreover, playing brain training games that are focused on specific executive function skills can have strong and consistent effects in improving these skills. However, although little progress has been made in schools that are still stuck in a 19th-century teaching model, it is revealed that the majority of teachers consider games to be an advantageous and powerful educational tool and are willing to adopt them in their courses (Ruggiero, 2013; Sánchez-Mena et al., 2019; Watson et al., 2013). Nowadays, cutting-edge technologies, such as virtual reality, augmented reality and $360^{\circ}$ videos, simplify the development of complex gaming systems without requiring advanced coding skills and programming and allow content experts to use them with ease and confidence (Deliyannis \& Kaimara, 2019; Kaimara et al., 2021; Kaimara et al., 2021). Thus, designers, educators and developers throughout a close collaboration will help in the smooth transition from traditional courses to courses through gamification and DGBL (Brunvand \& Hill, 2019).

In this context, the authors' research team focuses on examining the factors related to DGBL implementation and its perceived learning effectiveness in formal and informal educational settings. Undisputable fundamental factors in the educational process, i.e., teaching-learning, are teachers and learners. Authors' previous studies examined learners' views regarding digital educational games (Fokides et al., 2018, 2019a, b; Kaimara et al., 2019a, $2020 a$, b). Regarding the role of teachers, it is concluded that there have been several studies on teachers' (pre-service and in-service) attitudes towards ICT integration in schools, and their willingness to use innovative technology but not a sufficient number of studies on their intention to integrate gaming literacy within educational goals in Greece (Megagianni \& Kakana, 2021). Therefore, authors focused on teachers' views and particularly on Greek pre-service teachers' perceptions, the factors that influence their intention to utilise digital educational games, and their opinions regarding the potential barriers to integrating them into their teaching practice. The main reason for choosing pre-service teachers as a research target group is that they will soon start working in the real educational context. Additionally, they will be likely requested to implement DGBL and as a result authors consider that is essential to identify their readiness and their views since playing video games is a common form of entertainment for this generation (Martín-del-Pozo et al., 2017).

To study the teachers' attitude, the research team conducted a series of surveys on preservice teachers' perceptions regarding DGBL (Fokides \& Kaimara, 2020; Kaimara et al., 2019b; Kaimara \& Fokides, 2019). Quantitative data have shown that, although pre-service teachers seemed to agree that digital educational games have a positive effect on students, they are reluctant to use them as an educational tool. The only factors that influenced their attitudes were their gaming experience and the level of their technology skills. These results lead to the need to further investigate the reasons that shape pre-service teachers' opinions (Fokides \& Kaimara, 2020). Thus, a key question arose: since pre-service teachers' attitudes are positive, why are they reluctant to integrate them into their educational practice? Considering that digital literacy is increasingly penetrating everyday life and in particular of young people, several other questions require answers: what are the factors, internal and external, that influence the formation of young teachers' perceptions? Why are they hesitating to implement DGBL and what are the barriers they think prevent them? A secure way to identify these factors is to ask the persons directly involved through a quality survey. The qualitative approach is preferred for phenomena such as experiences, attitudes, and behaviours because it allows survey participants to freely express themselves through 
open-ended questions and thus facilitates researchers to achieve an in-depth understanding of participants views and to interpret the quantitative data (Hancock et al., 2009; Tenny et al., 2021).

For a comprehensive study on the pre-service teachers' views, an online survey was conducted which consisted of 33 closed-ended questions (quantitative approach) and an open-ended question (qualitative approach). This work presents the result of the qualitative approach based on the research question (RQ1). RQ1 was related to demographics and thus 5 more research questions emerged (Table 1$)$.

\section{Method}

The purpose of this study was to examine pre-service teachers' views on DGBL, and the possible obstacles that they consider to hinder its implementation in primary and secondary schools in Greece. To this end, as mentioned, an online survey was conducted (Kaimara et al., 2019b). The results of the overall research were based on qualitative and quantitative data collection methods. After registering the participants' answers to the open-ended question (qualitative data collection), we proceeded to quantitative analysis. Quantifying qualitative data ensures the drawing of more conclusions in relation to independent variables, such as age, gender, etc. Thus, each theme (T) was a dependent variable (DV), which then was correlated with the independent variables (IVs).

\subsection{Participants (target group) and duration of the study}

For this study, an invitation to fill an online questionnaire was published on Facebook pages which are maintained by groups of students from twenty-five University Departments preparing teachers for Primary and Secondary Education in Greece. Students were informed that the survey will be conducted voluntarily while the where also informed about the consent issues and permissions. The total number of recruited participants was 170. The questionnaire remained active for about one month and a half, from the beginning of February to the mid of March 2019.

Table 1 Research questions

\begin{tabular}{ll}
\hline & Research question \\
\hline RQ1 & $\begin{array}{c}\text { What do you think is/are the biggest barrier/s for integrating digital educational games into the } \\
\text { learning process? }\end{array}$ \\
RQ2a & $\begin{array}{c}\text { Are background studies related to the barriers pre-service teachers think that hinder the imple- } \\
\text { mentation of DGBL? }\end{array}$ \\
RQ2b $\quad$ Is gender related to the barriers pre-service teachers think that hinder the implementation of \\
DGBL?
\end{tabular}




\subsection{Instrument}

The questionnaire consisted of three online sections. In the first section, participants were asked to fill out their demographic information: department, gender, age, training in ICT and information about game-playing experience which were served as the study's independent variables (IVs). The second section focused on the participants' attitudes towards digital educational games formulated by 33 multiple-choice statements (close-ended questions) in a five-point Likert-type scale from 1 (strongly disagree) to 5 (strongly agree). The results of this quantitative section of the online questionnaire have already been presented (Kaimara et al., 2019b). The third section consisted of one open-ended question "What do you think is/are the biggest barrier/s for integrating digital educational games into the learning process?" that is the RQ1 and constituted the qualitative aspect of the research and the basis of this paper.

\subsubsection{Procedure and data processing}

The participants were asked to answer the open-ended question. A thematic coding analysis was considered appropriate for analyzing participants' responses to the open-ended question (Saldaña, 2015; Tenny et al., 2021). In short, the purpose of this procedure is to identify text passages that express -more or less- the same ideas/opinions, to index these passages into categories and to establish thematic ideas based on these categories (Gibbs, 2012). As participants' responses were already in a digital form, there was no need to transcribe them verbatim. Two experts in digital games acted as coders and for extracting the themes Atlas Ti was used. The coders' reliability was assessed both during a pilot test (using a randomly selected quarter of the responses) and formally during the coding of the complete data set. Rater consistency was assessed using Cohen's kappa and it was found to be very good $[\kappa=0.890, p<0.001,95 \%$ CI $(0.870,0.910)]$ (Landis \& Koch, 1977). The raters viewed all responses once, for identifying the main ideas. During a follow-up round, these ideas were labelled with codes and an initial set of themes emerged. This process was repeated once again and redundant codes and themes were removed. Quantitative data were obtained by counting the number of times a theme occurred, which is the most commonly used strategy for quantifying a set of qualitative data (Driscoll et al. 2007).

\section{Results}

The number of participants was 170 and the total number of valid responses was 276 (21 were excluded as they were vague or incomplete). Most participants were females $(N=122,71.8 \%)$. Almost half of them had a social sciences background $(N=79$, $46.5 \%)$; 63 (37.1\%) had a natural sciences background and $28(16.5 \%)$ had a specialization in special education. As expected, most participants belonged to the 18-23 yearsold age group $(N=111,65.3 \%)$; far fewer were between 24 and 30 years old $(N=35$, $20.6 \%)$ or even older $(N=24,14.2 \%)$. Unfortunately, most had no prior ICT training $(N=102,60 \%)$. Finally, it seems that participants' distribution in terms of their gaming experience in years of experience and gaming frequency was rather even, as is evident in Tables 2 and 3. 
Table 2 Years of gaming experience

Table 3 Gaming frequency

\begin{tabular}{llr}
\hline Years & & \\
\hline & $\mathrm{N}$ & $\%$ \\
\hline never & 38 & 22.4 \\
less than 2 years & 26 & 15.3 \\
2-8 years & 39 & 22.9 \\
9-15 years & 37 & 21.8 \\
Over 15 years & 30 & 17.6 \\
Total & 170 & 100.0 \\
\hline
\end{tabular}

\begin{tabular}{llr}
\hline Frequency & & \\
\hline & $\mathrm{N}$ & $\%$ \\
\hline Never & 43 & 25.3 \\
Occasionally, 1-3 days/month & 64 & 37.6 \\
Frequently, 1-3 days/week & 39 & 22.9 \\
Every day & 24 & 14.1 \\
Total & 170 & 100.0 \\
\hline
\end{tabular}

Table 4 Themes/potential barriers to the implementation of digital game-based learning in the classroom

\begin{tabular}{llc}
\hline Theme & Label & Responses \\
\hline T1 & Lack of financial resources & 68 \\
T2 & Preference to traditional teaching methods and stereotypical percep- & 65 \\
& $\quad$ tions about the value of digital games & 63 \\
T3 & Lack of ICT training & 56 \\
T4 & Lack of infrastructure & 24 \\
T5 & Lack of policy and framework & 276 \\
\end{tabular}

Five themes were identified in the process of coding the barriers (Table 3). The five themes that emerged representing the potential barriers in introducing DGBL in schools were:

- Lack of financial resources (e.g., financial crisis, cost and insufficient funding).

- Preference to traditional teaching methods and stereotypical perceptions about the value of digital games (e.g., distrust in the pedagogical game value, lecturing the preferred teaching method and lack of willingness to use more contemporary teaching methods).

- Lack of ICT training (e.g., poor teacher training in ICT and limited knowledge regarding how to integrate Digital games in teaching).

- Lack of infrastructure (e.g., lack of computers, technical assistance and software).

- Lack of policy and framework (e.g., negative policy-maker attitudes, curriculum and education system: stakeholders, education ministry, curriculum, educational system, lack of time for teachers to include games in the courses). 
Table 4 describes the five main barriers/themes from the most to least important according to the 276 responses of 170 pre-service teachers.

Indicatively, in addition to the direct responses related to a particular barrier, such as "financial resources" or "lack of teacher training", the most descriptive and complex answers are reported to show their breakdown across themes.

A female student with natural scientific background studies, aged 58 years old, without additional training in ICT, holding a laptop and a smartphone, who said that she had never played games, had positive attitudes and mentioned that the biggest barriers are:

"Curriculum design, information on positive outcomes, knowledge of how digital games are handled by teachers and their willingness to support the new way of learning".

This answer (no 52) split into, three themes (theme 2: preference to traditional teaching methods and stereotypical perceptions about the value of digital games, theme 3: Lack of ICT training and theme 5: Lack of policy and framework).

A male student, aged 38, with natural studies, holding a laptop and a smartphone, without training in ICT and game-playing experience considered that the barriers spread out among four themes (1, 2, 3 and 5):

"The conservative educational system, the lack of know-how from teachers, the reluctance of most educators to adapt to the technological developments and finally the lack of financial resources to implement this new educational system".

This particular answer (no 72) does not indicate the "lack of technological equipment" but as with most responses through qualitative analysis, most participants combined the lack of resources with the lack of modern equipment in schools. Although it is implied that a lack of financial resources is associated with a lack of technological equipment, it is not credited to theme 4 to maintain the objectivity of the answers.

In an answer (no 75), belonging to a 21-year-old female student coming from social studies holding a laptop and a smartphone, without game-playing experience, was referred that the biggest problem in implementing DGBL is a combination of the outdated educational system and teacher perceptions of the educational process who regard themselves as an authority (theme 2 and 5):

"Outdated perceptions of how the lesson 'should' take place, reinforced by teachers who have been practised the profession for years and believe themselves as an authority. In essence, the obstacle is the 'fear' that it will not work positively".

A female student coming from a department with a technological scientific background, aged 22, without additional training in ICT, holding a laptop and a smartphone, said she was playing games for less than 2 years and with occasional frequency, that is, 1 to 3 days a month, gave the following answer (no 143). In this response, issues that are related to perceptions about the teaching process based on more traditional methods (theme 2) and the organization of the educational system (theme 5), have been recognised as barriers:

"The structure of the educational system that promotes a specific way of teaching and the perceptions of how schools function are the two main factors that cannot easily 'open' the horizons to new educational methods such as new digital technologies. I believe that the combination of traditional teaching and new technologies could bring the best possible results in the whole learning process. It requires creativity and ingenuity in the context of the learning process so that 
children have an incentive to learn. And these components are undoubtedly found in digital games and if used properly they can stimulate students' interest in the learning subject being taught and thus make the learning process in which they are involved more effective".

A remarkable response (no 160) from a 21-year-old male student studying in a technology-department with no additional ICT training who has both a laptop and a smartphone and playing experience (every day for more than 15 years) is the following:

"As a person dealing with games, I have to admit that they are in no way compared to quality with the 'regular' learning provided in the school. Games are really a good way of learning, but from my experience, I have come to realize that a game succeeds only when it does not try a lot".

This response was included in theme 2 (preference to traditional teaching methods and stereotypical perceptions about the value of digital games) and theme 4 (lack of infrastructure).

The above themes served as the study's dependent variables (DVs), while gender, age, scientific background, ICT training, experience in playing games and game-playing frequency served as the study's independent variables (IVs). To examine the effects of the IVs on the DVs, a logistic regression analysis was to be performed. Before proceeding with the analysis, it was checked whether the assumptions for this type of analysis were met. Indeed, all the assumptions were satisfied as:

- The DVs were measured on a dichotomous scale.

- The IVs were either continuous or categorical.

- There was a linear relationship between any continuous IV and the logit transformation of the DVs.

As all the assumptions were met, a set of five logistic regression analysis was performed (one for each DV). It was found that:

T1 The logistic regression model was statistically significant $\left[\chi^{2}(14)=24.63, p=0.038\right]$. The model explained $18.2 \%$ (Nagelkerke $R^{2}=0.182$ ) of the variance in T1 and correctly classified $70.6 \%$ of cases. Then again, none of the IVs had an impact on T1.

T2 The logistic regression model was statistically significant $\left[\chi^{2}(14)=24.89, p=0.036\right]$. The model explained $18.5 \%$ (Nagelkerke $R^{2}=0.185$ ) of the variance in T2 and correctly classified $68.8 \%$ of cases. Participants having a natural sciences background were 3.92 times more likely to consider traditional teaching methods and stereotypical perceptions about the value of digital games as barriers for DGBL implementation than participants having a social sciences background $(p=0.048)$. Also, participants of the $24-30$ yearsold age group were 4.56 times more likely to have the above beliefs than participants of the 18-23 years-old age group $(p=0.033)$.

T3 The logistic regression model was not statistically significant $\left[\chi^{2}(14)=19.75, p=0.138\right]$. None of the IVs had an impact on T3.

T4 The logistic regression model was not statistically significant $\left[\chi^{2}(14)=15.25, p=0.361\right]$. None of the IVs had an impact on T4.

T5 The logistic regression model was not statistically significant $\left[\chi^{2}(14)=11.82, p=0.621\right]$. None of the IVs had an impact on T5. 
In short, the above results indicated that none of the IVs (namely, gender, age, scientific background, ICT training, experience in playing games and game-playing frequency) had an impact on DVs, i.e., lack of financial resources, lack of ICT training, lack of infrastructure and lack of policy and framework, as being barriers to the implementation of DGBL. On the other hand, participants having a natural sciences background, as well as participants of the 24-30 years-old age group, are more likely to consider the preference to traditional teaching methods and stereotypical perceptions about the value of digital games as being barriers to the implementation of DGBL, at least when compared to participants having a social sciences background and participants of the 18-23 years-old age group.

\section{Discussion}

In order to examine the views and in particular, the barriers that pre-service teachers assumed as important to overcome for DGBL implementation, we distributed a questionnaire targeting both our quantitative and qualitative analysis process with an open-ended question: "What do you think is/are the biggest barrier/s for integrating digital educational games into the learning process?" Students' answers to this question were intended to conclude the themes, namely the factors that are obstacles to DGBL implementation in formal education. The themes that have been extracted from the analysis were identified as DVs and correlated with the university department from which students were coming from, their gender, age and experience of playing games regarding the years and the frequency of playing. The scientific background of their studies, their gender, age and experience were the IVs.

The qualitative content analysis revealed five major themes as perceived barriers to DGBL implementation: (1) lack of financial resources, (2) preference to traditional teaching methods and stereotypical perceptions about the value of digital games, (3) lack of ICT training, (4) lack of infrastructure and (5) lack of policy and framework. The findings are in line with the literature review.

Regarding the financial resources, the cost of purchasing games and the lack of financial support are linked to outdated technology infrastructure in schools and therefore, limited budgets appear to be the most crucial inhibiting factor for implement DGBL. Thus, according to teachers' opinion, despite their positive attitudes and their intention to use digital games for teaching, it is assumed that there will be insufficient financial support (Baek, 2008; Klemetti et al., 2009; Li, 2017; Mozelius et al., 2017; Wu, 2015).

Considering the second perceived barrier, i.e., traditional approaches to the educational process adopted by the teachers, according to the logistic regression model, two of the IVs affected this DV. Research has shown that one of the major obstacles that hinder the diffusion of educational games into schools is teachers' prejudices and negative perceptions about game-based learning (Ketamo et al., 2013). Indeed, the debate between those academics, pre-service and in-service teachers who support the pedagogical benefits of digital games in the classroom and those who are more sceptical holds well since the late $80 \mathrm{~s}$, when computers were just starting to be seen as instructional technology for formal education with the latter to still consider the games do not have much to offer besides the traditional methods (Becker, 2010; Clark et al., 2010; Ruggiero, 2013; Watson et al., 2013). In the current research, the pre-service teachers with technological background were 3.92 times more likely to refer to the existence of traditional approaches to the educational process and the stereotypical perceptions of games as barriers to DGBL implementation 
than students with theoretical background $(p=0.048)$. Also, students between 24-30 years old were 4.56 times more likely to consider the existence of traditional approaches to the educational process and the stereotypical perceptions of games as barriers than students between 18-23 years old $(p=0.033)$. One could interpret this finding based on the fact that pre-service teachers who are slightly older than their 18-23 years old peers and have high technological knowledge, already have teaching experience through classroom practice and encountered the real situation in schools.

The third perceived obstacle concerns barriers under the umbrella of lack of ICT training and includes responses such as the poor teacher training in ICT, limited information through workshops and training programs on the positive effects of digital games, lack of teacher cooperation, problems of student collaboration during the game, indicating the lack of teachers' professional development (An, 2018; Hébert et al., 2021; Megagianni \& Kakana, 2021; Spiteri \& Chang Rundgren, 2020). Apart from the lack of know-how of games implementation in education regarding their content and the gameplay, this factor also reflects issues related to classroom management while playing (Martín-del-Pozo et al., 2017; Watson et al., 2013; Wu, 2015).

The lack of technological equipment/infrastructure both for devices/hardware and software referred to as the fourth barrier: purchase, maintenance and update both of hardware and software such as educational games are the prerequisites of successful implementation and require a great amount of financial investment (Hébert et al., 2021; Li, 2017; Mertala, 2019).

Finally, twenty-four responses were reported which are related to the education system. This factor reflects the barriers that pre-service teachers have recognised that they are deriving from those who form educational policy, structure the education system and design curricula. Considering that these twenty-four answers came from a total of 170 responses, it is concluded that this sample of pre-service teachers believes that the Greek educational system has been modernised, is in line with international trends and is not the biggest obstacle to the implementation of DGBL.

According to quantitative analysis, except the theme 2 "preference to traditional teaching methods and stereotypical perceptions about the value of digital games", in which two of the IVs had an impact, (i.e., natural science background and age), all the other themes flow through the entire sample regardless of the scientific background, gender, age and years/frequency of playing. One possible explanation for this group attitude towards ICT may be related to the viewpoint of their university professors who teach ICT-related courses and the overall syllabus in natural studies departments (Vourletsis \& Politis, 2017).

Based on the study findings, the subsequent analysis and the five themes overall evaluation, it can be concluded that pre-service teachers identified two major obstacles resulting: the external that is the funding and the internal that is the attitudes both of policy-makers and teachers. Referring to teachers' perceptions, it is important to analyse the response (no 160) of the 21-year-old student who often plays games and has the technological background: "As a person dealing with games, I have to admit that they are (games) in no way compared to quality with the 'regular' learning provided in the school. Games are really a good way of learning, but from my experience, I have come to realize that a game succeeds only when it does not try a lot". This finding is also cited in the literature as, while the higher education students would be expected to have positive attitudes towards the use of technology for teaching and learning, due to the everincreasing use of technology, they appear far more reluctant to technology adoption in education than their level of digital media exposure would suggest (Groff, 2013). Additionally, student's answer perhaps reflects the core of the problem of games integration 
into education: the public opinion of "what actually constitutes valid and valuable educational activity and concerning the gaming as a purely pleasurable pastime rather than a challenging complex of social activities and skills" (Williamson, 2009, p. 35). Bensiger (2012) also concluded that pre-service teachers were not aware of the pedagogical dimensions of video games, but rather perceived them simply as positive rewards for good student behaviour in the classroom and not as a tool for learning new concepts.

Proponents of games in school have to overcome the objections of those who perceive games as insufficiently serious, that they are "just play" (Klopfer et al., 2009). Mayer (2019) reported the progress being made by research in three areas. The first area is examining the games features that promote learning, the second is about the cognitive consequences, (i.e., learning analytics and outcomes related to what is learned by playing games, including measures of cognitive and motivational processes during learning) and the third area is employing media comparison that provides answers to the question of whether people learn better from games than from conventional media. Therefore, the value-added of the 21-year-old student's view could be taken into consideration by the design teams: through a game, one can undoubtedly learn, as long as the educational objectives are effortlessly achieved. If the student appreciates that the games are just another tool for teaching and assessing his knowledge, then it is not much different from a traditional course, it is just more fun and entertaining and so, we will return to the stigma that games are "play" and thus the opposite of "work" (Ifenthaler et al., 2012; Van Eck, 2006).

Ultimately, the key problem regarding DGBL introduction in formal education is related to the perception of technology as a tool rather than a system or set of affordances (Blewett, 2016, p. 265). Teachers' intention to use educational games in their courses relies on their perceived usefulness that influences directly and positively teachers' attitudes (Sánchez-Mena et al., 2017a, b). Teachers having very well-documented principles from different learning theories could combine the exciting benefits of digital media with a variety of platforms and real-life experiences, gamification techniques and truly learner-focused pedagogies to provide productive, collaborative, creative, meaningful and powerful learning experiences utilising affordable and easy-to-use devices (Fleming, 2013; Kaimara, et al., 2019, 2020). This concept consists of the notion of transmedia learning (Kaimara et al., 2021, 2021).

\section{Limitations and future work}

This study was limited to 170 students, coming from twenty-five University Departments with a variety of theoretical and technological disciplines which are preparing teachers for Primary and Secondary Education in Greece. 276 valid responses to the open-ended question were recorded. The data were collected in one month and a half. The authors further extend the research with in-service teachers to correlate their views with those of pre-service teachers. Currently, answers are being collected using the same questionnaire with the 33 closed-ended questions and the single open-ended question. At a time when online education is imperative, due to the SARS-CoV-2 pandemic and the forced social distancing and schools closure, research is challenging. In conditions where learning is performed digitally, it is very important to savvy if teachers' views on the value of digital games in the learning process have changed. 


\section{Conclusion}

Games have a prominent place in learning technologies due to their possibilities to motivate students to explore the edges of their competence, skills and knowledge. Important influences related to their effective implementation are teachers, students and the educational game per se. This paper focused on the identification of Greek pre-service teachers' views, who are currently studying in the pedagogical university departments, for DGBL, their intention to integrate digital games into the educational process and their opinion regarding possible barriers to this integration. The views of the pre-service teachers' opinions are particularly important because they will soon be working in schools. The collected data were analysed qualitatively and quantitatively. Among the main obstacles, pre-service teachers highlighted the lack of financial resources, the preference for traditional teaching methods and stereotypes about the value of digital games, the lack of ICT training, the lack of infrastructure and the lack of educational policy. The results indicated that the Greek pre-service teachers' views are largely in line with the findings from international literature. Conclusions have particular relevance and importance because they derived from unbiased answers to an open-ended question. The barriers mentioned by pre-service teachers are divided into two categories, the external (e.g., lack of financial resources, teacher training and limited technological equipment and the internal (e.g., teachers' beliefs about their role in the educational process). Teachers' perceptions were influenced by external factors such as policy. However, educational policy is designed by people and therefore if at first sight policy is an external factor that defines the context of the educational system and provides the guidelines to teachers, a more in-depth review reveals that it is directly related to the beliefs and perceptions of those who administer, either within ministries or schools.

According to the time range of studies identified during the literature review, the debate on the value of digital educational games and their place in formal education continues to be in the spotlight. The proponents of DGBL ought to put forward tangible evidence for its learning outcomes. These arguments will also be the lever for changing teachers' views who are still attached to traditional teaching models. Besides, without convincing responses from academics and practitioners, it would not be possible to integrate innovative methods through stakeholders. According to the pre-service teachers' responses, it is concluded that the general barrier is mainly economic. Economic does not relate to the lack of financial resources but essentially to rationalize the allocation of resources. Resources are needed to acquire up-to-date equipment, devices and software, teacher training as well as administrators and educational policymakers training. However, the use of handy and inexpensive devices, which almost all teachers even students hold (BYOD-Bring Your Own Device policy) (Attewell, 2017), is the answer to the obstacle called "lack of equipment". Therefore, DGBL implementation, as a smart and innovative pedagogical approach, is primarily a matter of policy willingness to curriculum reform based on current research on adequate digital learning materials.

Funding The study received no funding.

\section{Declarations}

Conflict of interest The authors declare that they have no conflict of interest. 


\section{References}

An, Y. (2018). The effects of an online professional development course on teachers' perceptions, attitudes, self-efficacy, and behavioral intentions regarding digital game-based learning. Educational Technology Research and Development. https://doi.org/10.1007/s11423-018-9620-z.

Attewell, J. (2017). BYOD for Schools: Technical advice for school leaders and IT administrators. In J. Ayre (Ed.), European schoolnet's interactive classroom working group (ICWG). European Schoolnet (EUN Partnership AISBL).

Baek, Y. K. (2008). What hinders teachers in using computer and video games in the classroom? Exploring factors inhibiting the uptake of computer and video games. Cyber Psychology \& Behavior, 11(6), 665-671. https://doi.org/10.1089/cpb.2008.0127.

Becker, K. (2010). The Clark-Kozma Debate in the 21st Century. In CNIE conference 2010, "heritage matters: Inspiring tomorrow”.

Bell, A., \& Gresalfi, M. (2017). Teaching with videogames: How experience impacts classroom integration. Technology, Knowledge and Learning, 22(3), 513-526. https://doi.org/10.1007/ s10758-017-9306-3.

Bensiger, J. (2012). Perceptions of preservice teachers of using video games as teaching tools [University of Cincinnati]. In Ph. D Dissertation. https://etd.ohiolink.edu/!etd.send_file?accession=ucin 1 337363651\&disposition=inline

Blewett, C. (2016). From traditional pedagogy to digital pedagogy: Paradoxes, affordances, and approaches. In M. A. Samuel, R. Dhunpath, \& N. Amin (Eds.), Disrupting higher education curriculum. Constructing knowledge: Curriculum studies in action. (pp. 264-287). SensePublishers. https://doi.org/10.1007/978-94-6300-896-9_16

Bourgonjon, J., De Grove, F., De Smet, C., Van Looy, J., Soetaert, R., \& Valcke, M. (2013). Acceptance of game-based learning by secondary school teachers. Computers \& Education, 67, 21-35. https:// doi.org/10.1016/j.compedu.2013.02.010.

Bourgonjon, J., Valcke, M., Soetaert, R., \& Schellens, T. (2010). Students' perceptions about the use of video games in the classroom. Computers \& Education, 54(4), 1145-1156. https://doi.org/10. 1016/j.compedu.2009.10.022.

Brunvand, S., \& Hill, D. (2019). Gamifying your teaching: Guidelines for integrating gameful learning in the classroom. College Teaching, 67(1), 58-69. https://doi.org/10.1080/87567555.2018.1518893.

Clark, D. B., Tanner-Smith, E. E., \& Killingsworth, S. S. (2016). Digital games, design, and learning: A systematic review and meta-analysis. Review of Educational Research, 86(1), 79-122. https://doi. org/10.3102/0034654315582065.

Clark, R. E. (2007). Learning from serious games? Arguments, evidence, and research suggestions. Educational Technology, 47(3), 56-59.

Clark, R. E., Yates, K., Early, S., \& Moulton, K. (2010). An analysis of the failure of electronic media and discovery-based learning. In K. H. Silber, W. R. Foshay, R. Watkins, D. Leigh, J. L. Moseley, \& J. C. Dessinger (Eds.), Handbook of improving performance in the workplace: Volumes 1-3 (Vol. 1, pp. 263-297). Wiley. https://doi.org/10.1002/9780470592663.ch8

Daniela, L. (2019). Didactics of smart pedagogy. In L. Daniela (Ed.), Didactics of smart pedagogy: Smart pedagogy for technology enhanced learning. Springer International Publishing. https://doi. org/10.1007/978-3-030-01551-0

Daniela, L. (2020). Concept of smart pedagogy for learning in a digital world. In Epistemological approaches to digital learning in educational contexts (pp. 1-16). Routledge. https://doi.org/10. 4324/9780429319501-1

Daniela, L., \& Lytras, M. (2018). SMART pedagogy: (Re) defining pedagogy. In L Daniela \& M. Lytras (Eds.), Learning strategies and constructionism in modern education settings (pp. 1-15). IGI Global. https://doi.org/10.4018/978-1-5225-5430-1.ch001

Daniela, L, \& Žogla, I. (2013). Future teachers' views on using digital media in teaching. In D. Parmigiani, V. Pennazio, \& A. Traverso (Eds.), Learning \& teaching with media \& technology. ATEESIREM Winter conference proceedings (pp. 21-29). ATEE aisbl. http://www.ateegenoa2013.sdf. unige.it/images/proceedings/proceedings_atee_genoa_2013rid.pdf

Davis, F. D. (1986). A technology acceptance model for empirically testing new end-user information systems: Theory and results [Massachusetts Institute of Technology]. https://dspace.mit.edu/handle/1721.1/15192

de Freitas, S., \& Liarokapis, F. (2011). Serious games: A new paradigm for education? In M. Ma, A. Oikonomou, \& L. Jain (Eds.), Serious games and edutainment applications (pp. 9-23). Springer. https://doi.org/10.1007/978-1-4471-2161-9_2 
De Grove, F., Bourgonjon, J., \& Van Looy, J. (2012). Digital games in the classroom? A contextual approach to teachers' adoption intention of digital games in formal education. Computers in Human Behavior, 28(6), 2023-2033. https://doi.org/10.1016/j.chb.2012.05.021.

Deliyannis, I., \& Kaimara, P. (2019). Developing smart learning environments using gamification techniques and video game technologies. In L. Daniela (Ed.), Didactics of smart pedagogy (pp. 285-307). Springer International Publishing. https://doi.org/10.1007/978-3-030-01551-0_15

Deterding, S., Dixon, D., Khaled, R., \& Nacke, L. (2011). From game design elements to gamefulness. In Proceedings of the 15th international academic MindTrek conference: Envisioning future media environments (pp. 9-15). https://doi.org/10.1145/2181037.2181040

Driscoll, D. L., Appiah-Yeboah, A., Salib, P., \& Rupert, D. J. (2007). Merging qualitative and quantitative data in mixed methods research: How to and why not. Ecological and Environmental Anthropology, 3(1), 19-28.

Erhel, S., \& Jamet, E. (2019). Improving instructions in educational computer games: Exploring the relations between goal specificity, flow experience and learning outcomes. Computers in Human Behavior, 91, 106-114. https://doi.org/10.1016/j.chb.2018.09.020.

Ertmer, P. (1999). Addressing first- and second-order barriers to change: Strategies for technology integration. Educational Technology Research and Development, 47(4), 47-61. https://doi.org/10.1007/ BF02299597.

Fleming, L. (2013). Expanding learning opportunities with transmedia practices: Inanimate alice as an exemplar. Journal of Media Literacy Education, 5(2), 370-377.

Fokides, E. (2020). Digital educational games in primary education. In L. Daniela (Ed.), Epistemological approaches to digital learning in educational contexts (pp. 54-68). Routledge. https://doi.org/10.4324/ 9780429319501-4

Fokides, E., Atsikpasi, P., Kaimara, P., \& Deliyannis, I. (2019a). Factors influencing the subjective learning effectiveness of serious games. Journal of Information Technology Education: Research, 18, 437-466. https://doi.org/10.28945/4441.

Fokides, E., Atsikpasi, P., Kaimara, P., \& Deliyannis, I. (2019b). Let players evaluate serious games. Design and validation of the Serious Games Evaluation Scale. International Computer Games AssociationICGA. https://doi.org/10.3233/ICG-190111

Fokides, E., \& Kaimara, P. (2020). Future teachers' views on digital educational games (Oı $\alpha \pi$ ó $\psi \varepsilon 1 \varsigma \tau \omega \nu$

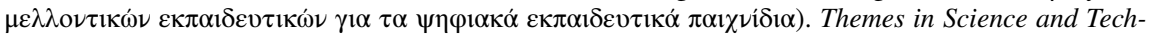
nology Education, 13(1/2), 83-95. http://earthlab.uoi.gr/thete/index.php/thet

Fokides, E., Kaimara, P., Deliyannis, I., \& Atsikpasi, P. (2018). Development of a scale for measuring the learning experience in serious games. In M. Panagopoulos, A. Papadopoulou, \& A. Giannakoulopoulos (Eds.), 1st international conference digital culture and audiovisual challenges, interdisciplinary creativity in arts and technology, Corfu, Greece, June 1-2, 2018.: Vol. 2811 (pp. 181-186). CEURWS. http://ceur-ws.org/Vol-2811/Paper26.pdf

Fokides, E., \& Kostas, A. (2020). Pre-service teachers and computers: a (still) troubled relationship. In L. Tomei \& D. Carbonara (Eds.), Handbook of research on diverse teaching strategies for the technologyrich classroom (pp. 15-31). IGI Global. https://doi.org/10.4018/978-1-7998-0238-9.ch002

Gee, J. P. (2003). What video games have to teach us about learning and literacy. . Palgrave Macmillan.

Gee, J. P. (2008). Learning and games. In K. Salen (Ed.), The ecology of games: Connecting youth, games, and learning (pp. 21-40). The John D. and Catherine T. MacArthur Foundation Series on Digital Media and Learning. The MIT Press. https://doi.org/10.1162/dmal.9780262693646.021

Gibbs, G. (2012). Thematic coding and categorizing. In Analyzing qualitative data (pp. 38-55). SAGE Publications, Ltd. https://doi.org/10.4135/9781849208574.n4

Girard, C., Ecalle, J., \& Magnan, A. (2013). Serious games as new educational tools: How effective are they? A meta-analysis of recent studies. Journal of Computer Assisted Learning, 29(3), 207-219. https://doi.org/10.1111/j.1365-2729.2012.00489.x.

Goodwyn, A., Adams, A., \& Clarke, S. (1997). The great god of the future: the views of current and future English Teachers on the Place of IT in Literacy. English in Education, 31(2), 54-62. https://doi.org/10. 1111/j.1754-8845.1997.tb00125.x.

Gray, P. (2008). Children educate themselves II: We all know that's true for little kids. FREEDOM TO LEARN:The Roles of Play and Curiosity as Foundations for Learning. https://www.psychologytoday. com/intl/blog/freedom-learn/200807/children-educate-themselves-ii-lessons-little-kids

Groff, J. (2013). Technology-rich innovative learning environments. http://www.oecd.org/education/ceri/ Technology-Rich\%20Innovative\%20Learning\%20Environments\%20by\%20Jennifer\%20Groff.pdf

Gunter, G. a, Kenny, R. F., \& Vick, E. H. (2006). A case for a formal design paradigm for serious games. The Journal of the International Digital Media and Arts Association, 3(1), 93-105. http://www.units. miamioh.edu/codeconference/papers/papers/Gunter Kenny Vick paper.pdf 
Hamari, J., \& Nousiainen, T. (2015). Why do teachers use game-based learning technologies? The role of individual and institutional ICT readiness. In 2015 48th Hawaii international conference on system sciences, 682-691. https://doi.org/10.1109/HICSS.2015.88

Hamari, J., Shernoff, D. J., Rowe, E., Coller, B., Asbell-Clarke, J., \& Edwards, T. (2016). Challenging games help students learn: An empirical study on engagement, flow and immersion in game-based learning. Computers in Human Behavior, 54, 170-179. https://doi.org/10.1016/j.chb.2015.07.045.

Hancock, B., Ockleford, E., \& Windridge, K. (2009). An introduction to qualitative research. The NIHR RDS EM/YH. https://www.rds-yh.nihr.ac.uk/wp-content/uploads/2013/05/5_Introduction-to-quali tative-research-2009.pdf

Hébert, C., Jenson, J., \& Terzopoulos, T. (2021). "Access to technology is the major challenge": Teacher perspectives on barriers to DGBL in K-12 classrooms. E-Learning and Digital Media. https://doi. org/10.1177/2042753021995315.

Hersh, M., \& Leporini, B. (2018). Editorial: Serious games, education and inclusion for disabled people. British Journal of Educational Technology, 49(4), 587-595. https://doi.org/10.1111/bjet.12650.

Hewes, J. (2014). Seeking balance in motion: The role of spontaneous free play in promoting social and emotional health in early childhood care and education. Children, 1(3), 280-301. https://doi.org/10. 3390/children1030280.

Huizenga, J. C., ten Dam, G. T. M., Voogt, J. M., \& Admiraal, W. F. (2017). Teacher perceptions of the value of game-based learning in secondary education. Computers \& Education, 110, 105-115. https://doi.org/10.1016/j.compedu.2017.03.008.

Ifenthaler, D., Eseryel, D., \& Ge, X. (2012). Assessment for game-based learning. In Assessment in game-based learning: Foundations, innovations, and perspectives (pp. 1-8). Springer. https://doi. org/10.1007/978-1-4614-3546-4_1

Jimoyiannis, A., \& Komis, V. (2007). Examining teachers' beliefs about ICT in education: Implications of a teacher preparation programme. Teacher Development, 11(2), 149-173. https://doi.org/10. 1080/13664530701414779.

Kaimara, P., \& Deliyannis, I. (2019). Why should i play this game? The role of motivation in smart pedagogy. In L. Daniela (Ed.), Didactics of smart pedagogy (pp. 113-137). Springer, Cham. https:// doi.org/10.1007/978-3-030-01551-0_6

Kaimara, P., Deliyannis, I., Oikonomou, A., Fokides, E., \& Miliotis, G. (2021). An innovative transmedia-based game development method for inclusive education. Digital Culture \& Education, (in press)(Special Issue: International Perspectives on Digital Games and Inclusion). https://www.digit alcultureandeducation.com/browse-journal

Kaimara, P., \& Fokides, E. (2019). Future teachers' views on digital educational games (in greek: Oı

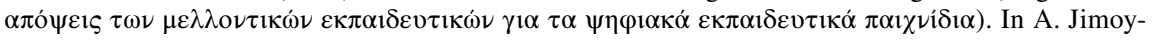
iannis \& P. Tsiotakis (Eds.), 2nd Pan-hellenic Conference: Open Educational Resources and E-Learning (p. 41). Department of Social and Education Policy of the University of Peloponnese \& Hellenic Association of ICT in Education (HAICTE).

Kaimara, P., Fokides, E., Oikonomou, A., Atsikpasi, P., \& Deliyannis, I. (2019a). Evaluating 2D and 3D serious games: The significance of student-player characteristics. Dialogoi! Theory and Praxis in Education, 5, 36-56. https://doi.org/10.12681/dial.20704.

Kaimara, P., Fokides, E., Oikonomou, A., \& Deliyannis, I. (2019b). Undergraduate students' attitudes towards collaborative digital learning games. In Proceedings of 2 nd international conference digital culture and audiovisual challenges, interdisciplinary creativity in arts and technology, May 10-11, Corfu, Greece., Book of Abstracts, 63-64. https://avarts.ionio.gr/dcac/2019/en/schedule/

Kaimara, P., Fokides, E., Plerou, A., Atsikpasi, P., \& Deliyannis, I. (2020). Serious games effect analysis on player's characteristics. International Journal of Smart Education and Urban Society, 11(1), 75-91. https://doi.org/10.4018/IJSEUS.2020010106.

Kaimara, P., Oikonomou, A., Deliyannis, I., Papadopoulou, A., Miliotis, G., Fokides, E., \& Floros, A. (2021). Waking up in the morning (WUIM): A transmedia project for daily living skills training. Technology and Disability (in press).

Kaimara, P., Poulimenou, S.-M., \& Deliyannis, I. (2020). Digital learning materials: Could transmedia content make the difference in the digital world? In L. Daniela (Ed.), Epistemological approaches to digital learning in educational contexts (pp. 69-87). Routledge. https://doi.org/10.4324/97804 29319501-5

Kaimara, P., Poulimenou, S.-M., Oikonomou, A., Deliyannis, I., \& Plerou, A. (2019). Smartphones at schools? Yes, why not? European Journal of Engineering Research and Science, SPECIAL ISSUE: CIE 2018, 1-6. https://doi.org/10.24018/ejers.2019.0.CIE.1288

Keller, J. M. (2016). Motivation, learning, and technology: Applying the ARCS-V motivation model. Participatory Educational Research, 3(2), 1-15. https://doi.org/10.17275/per.16.06.3.2. 
Ketamo, H., Kiili, K., Arnab, S., \& Dunwell, I. (2013). Integrating games into the classroom. In New pedagogical approaches in game enhanced learning (pp. 114-135). IGI Global. https://doi.org/10. 4018/978-1-4666-3950-8.ch007

Klemetti, M., Taimisto, O., \& Karppinen, P. (2009). The attitudes of finnish school teachers towards commercial educational games. In Design and use of serious games (pp. 97-105). Springer Netherlands. https://doi.org/10.1007/978-1-4020-9496-5_7

Klopfer, E., Osterweil, S., \& Salen, K. (2009). Moving learning games forward, obstacles opportunities \& openness. The Education Arcade. http://citeseerx.ist.psu.edu/viewdoc/download?doi=10.1.1.687. $5017 \&$ rep $=$ rep1\&type $=$ pdf

Koh, E., Kin, Y. G., Wadhwa, B., \& Lim, J. (2012). Teacher perceptions of games in Singapore schools. Simulation \& Gaming, 43(1), 51-66. https://doi.org/10.1177/1046878111401839.

Landis, J. R., \& Koch, G. G. (1977). The measurement of observer agreement for categorical data. Biometrics, 33(1), 159-174. https://doi.org/10.2307/2529310.

Li, C. (2017). Attitudes towards digital game-based learning of chinese primary school english teachers [The University of Edinburgh]. https://www.era.lib.ed.ac.uk/handle/1842/31039

Makransky, G., Borre-Gude, S., \& Mayer, R. E. (2019). Motivational and cognitive benefits of training in immersive virtual reality based on multiple assessments. Journal of Computer Assisted Learning, 35(6), 691-707. https://doi.org/10.1111/jcal.12375.

Martín-del-Pozo, M., Basilotta Gómez-Pablos, V., \& García-Valcárcel Muñoz-Repiso, A. (2017). A quantitative approach to pre-service primary school teachers' attitudes towards collaborative learning with video games: Previous experience with video games can make the difference. International Journal of Educational Technology in Higher Education, 14(1), 11. https://doi.org/10.1186/s41239-017-0050-5.

Martín-del-Pozo, M., García-Valcárcel Muñoz-Repiso, A., \& Hernández Martín, A. (2019). Video games and collaborative learning in education? A scale for measuring in-service teachers' attitudes towards collaborative learning with video games. Informatics, 6(3), 30. https://doi.org/10.3390/informatic s6030030.

Mayer, R. (2019). Computer games in education. Annual Review of Psychology, 70, 531-549. https://doi. org/10.1146/annurev-psych-010418-102744.

Megagianni, P., \& Kakana, D. (2021). The educational value and impact of serious games in cognitive, social and emotional development in middle childhood: perceptions of teachers in Greece. In T. Tsiatsos, S. Demetriadis, A. Mikropoulos, \& V. Dagdilelis (Eds.), Research on E-learning and ICT in education (pp. 129-145). Springer International Publishing. https://doi.org/10.1007/978-3-030-64363-8_8

Mertala, P. (2019). Digital technologies in early childhood education-A frame analysis of preservice teachers' perceptions. Early Child Development and Care, 189(8), 1228-1241. https://doi.org/10.1080/ 03004430.2017 .1372756 .

Mishra, P., \& Koehler, M. J. (2006). Technological pedagogical content knowledge: A framework for teacher knowledge. Teachers College Record, 108(6), 1017-1054. https://doi.org/10.1111/j.1467-9620. 2006.00684.x.

Mozelius, P., Hernandez, W., Sällström, J., \& Hellerstedt, A. (2017). Teacher attitudes toward game-based learning in history education. International Journal of Information and Communication Technologies in Education, 6(4), 27-35. https://doi.org/10.1515/ijicte-2017-0017.

Mumtaz, S. (2000). Factors affecting teachers' use of information and communications technology: A review of the literature. Journal of Information Technology for Teacher Education, 9(3), 319-342. https://doi.org/10.1080/14759390000200096.

National Academies of Sciences Engineering and Medicine. (2018). How people learn II. National Academies Press. https://doi.org/10.17226/24783

OER. (2018). Teachers at the heart of system change: A consolidation of OER research (National Institute of Education Singapore (ed.)). Office of Education Research. https://www.nie.edu.sg/docs/defau 1t-source/oer/oer_rcr_final_for_web_v2.pdf?sfvrsn=0

Papadakis, S. (2018). The use of computer games in classroom environment. International Journal of Teaching and Case Studies, 9(1), 1-25. https://doi.org/10.1504/IJTCS.2018.090191.

Pivec, M. (2007). Editorial: Play and learn: Potentials of game-based learning. British Journal of Educational Technology, 38(3), 387-393. https://doi.org/10.1111/j.1467-8535.2007.00722.x.

Plass, J. L., Homer, B. D., \& Kinzer, C. K. (2015). Foundations of game-based learning. Educational Psychologist, 50(4), 258-283. https://doi.org/10.1080/00461520.2015.1122533.

Prensky, M. (2007). Digital game-based learning. . Paragon House.

Ruggiero, D. (2013). Video games in the classroom: The teacher point of view. In Games for learning workshop of the foundations of digital games conference. http://fdg2013.org/program/workshops/ papers/G4L2013/g412013_02.pdf

Saldaña, J. (2015). The Coding Manual for Qualitative Researchers. (3rd ed.). SAGE Publications Ltd. 
Salen, K., \& Zimmerman, E. (2004). Rules of play_Game design fundamentals. Massachusetts Institute of Technology. https://gamifique.files.wordpress.com/2011/11/1-rules-of-play-game-design-fundamenta ls.pdf

Sánchez-Mena, A., \& Martí-Parreño, J. (2017). Drivers and barriers to adopting gamification: Teachers' perspectives. The Electronic Journal of E-Learning, 15(5), 434-443.

Sánchez-Mena, A., Martí-Parreño, J., \& Aldás-Manzano, J. (2017). The role of perceived relevance and attention in teachers' attitude and intention to use educational video games. International Journal of Emerging Technologies in Learning (IJET), 12(03), 154-168. https://doi.org/10.3991/ijet.v12i03.6505.

Sánchez-Mena, A., Martí-Parreño, J., \& Aldás-Manzano, J. (2017). The effect of age on teachers' intention to use educational video games: A TAM approach. The Electronic Journal of E-Learning, 15(4), 355-366.

Sánchez-Mena, A., Martí-Parreño, J., \& Aldás-manzano, J. (2019). Teachers’ intention to use educational video games: The moderating role of gender and age. Innovations in Education and Teaching International, 56(3), 318-329. https://doi.org/10.1080/14703297.2018.1433547.

Schrader, P. G., Zheng, D., \& Young, M. (2006). Teachers' perceptions of video games: MMOGs and the future of preservice teacher education. Innovate: Journal of Online Education, 2(3). https://www.learn techlib.org/p/104278/

Spiteri, M., \& Chang Rundgren, S.-N. (2020). Literature review on the factors affecting primary teachers' use of digital technology. Technology, Knowledge and Learning, 25(1), 115-128. https://doi.org/10. 1007/s10758-018-9376-X.

Tenny, S., Brannan, G. D., Brannan, J. M., \& Sharts-Hopko, N. C. (2021). Qualitative Study. In I. StatPearls (Ed.), StatPearls. StatPearls Publishing. http://www.ncbi.nlm.nih.gov/pubmed/29262162

Tomczyk, Ł, Jáuregui, V. C., de La Higuera Amato, C. A., Muñoz, D., Arteaga, M., Oyelere, S. S., Akyar, Ö. Y., \& Porta, M. (2020). Are teachers techno-optimists or techno-pessimists? A pilot comparative among teachers in Bolivia, Brazil, the Dominican Republic, Ecuador, Finland, Poland, Turkey, and Uruguay. Education and Information Technologies. https://doi.org/10.1007/s10639-020-10380-4.

Van Eck, R. (2006). Digital game-based learning: It's not just the digital natives who are restless. Educause Review. https://doi.org/10.1145/950566.950596.

Van Eck, R. N., Guy, M., Young, T., Winger, A. T., \& Brewster, S. (2015). Project NEO: A video game to promote STEM competency for preservice elementary teachers. Technology, Knowledge and Learning, 20(3), 277-297. https://doi.org/10.1007/s10758-015-9245-9.

Vourletsis, I., \& Politis, P. (2017). Differences in attitudes towards ICT in education between freshmen and senior students of department of primary education in Greece. In P. Anastasiades \& N. Zaranis (Eds.), Research on e-learning and ICT in education (pp. 217-229). Springer International Publishing. https:// doi.org/10.1007/978-3-319-34127-9_16

Watson, W., Yang, S., \& Ruggiero, D. (2013). Games in schools: Teachers' perceptions of barriers to gamebased learning. In M. Simonson (Ed.), The annual convention of the association for educational communications and technology (Vol. 1, pp. 229-238). https://files.eric.ed.gov/fulltext/ED546877.pdf\# page $=238$

Williamson, B. (2009). Computer games, schools, and young people: A report for educators on using games for learning. In Futurelab. https://www.nfer.ac.uk/publications/FUTL27/FUTL27.pdf

Wu, M. L. (2015). Teachers' experience, attitudes, self-efficacy and perceived barriers to the use of digital game-based learning: A survey study through the lens of a typology of educational digital games [Michigan State University]. In ProQuest Dissertations and Theses. https://d.lib.msu.edu/etd/3754

Zosh, J. M., Hopkins, E. J., Jensen, H., Liu, C., Neale, D., Hirsh-Pasek, K., Solis, S. L., \& Whitebread, D. (2017). Learning through play: A review of the evidence (white paper).

Publisher's Note Springer Nature remains neutral with regard to jurisdictional claims in published maps and institutional affiliations. 


\section{Authors and Affiliations}

\section{Polyxeni Kaimara ${ }^{1}$ (D) Emmanuel Fokides ${ }^{2}$ (D) Andreas Oikonomou $^{3}$ (D) . Ioannis Deliyannis ${ }^{1}$}

Emmanuel Fokides

fokides@aegean.gr

Andreas Oikonomou

aoikonomou@aspete.gr

Ioannis Deliyannis

yiannis@ionio.gr

1 Department of Audio and Visual Arts, Ionian University, Tsirigoti Sq. 7, 49100 Corfu, Greece

2 Department of Primary School Education, University of the Aegean, Dimokratias 1, 85132 Rhodes, Greece

3 School of Pedagogical and Technological Education (ASPETE), Alexandrou Papanastasiou 13, 54639 Thessaloniki, Greece 